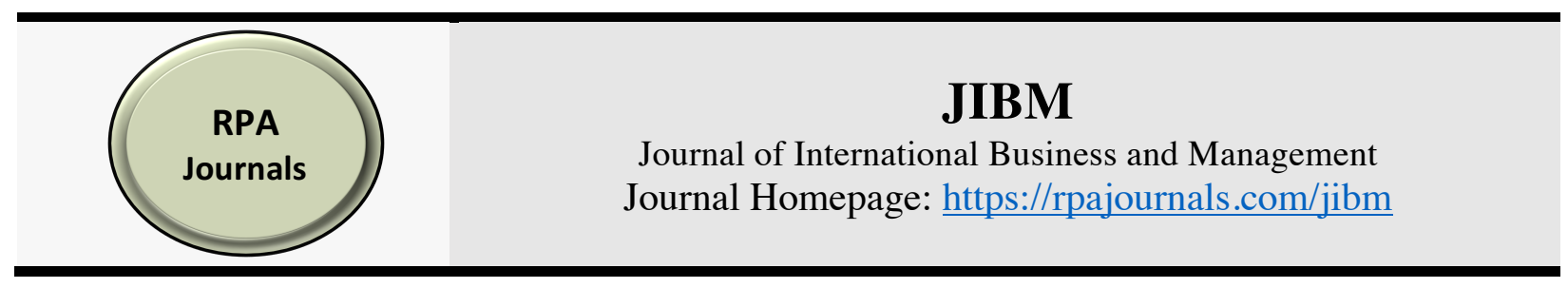

\title{
Explaining Firms' Behavioral Intention towards Environmental Reporting in Bangladesh: An Application of Theory of Planned Behavior
}

\author{
S.M. Shafiul Alam \\ Salma Akter ${ }^{2}$ \\ M. Helal Uddin Ahmed \\ Ahsanullah University of Science and Technology, Bangladesh ${ }^{12}$ \\ University of Dhaka, Bangladesh ${ }^{3}$
}

\begin{abstract}
Environmental reporting is getting significant momentum worldwide due to its substantial effects towards sustainable development goals. This study aims at probing for salient factors that determine the intention to disclose environmental credentials in the sustainability reports. In this study primary data have been gathered from 53 listed textile firms of Bangladesh Securities and Exchange Commission (BSEC). Five point measurement scale has been used to gauge the data which were eventually analyzed through structural equation modeling (SEM). The Theory of Planned Behavior (TPB) is applied to understand the interplay among the determinants of intentions towards environmental reporting. It has been revealed that subjective norms (social expectation/authoritative pressure) are the most powerful determinants for developing intention to engage in environmental reporting behavior. Perceived behavioral control (ability/ difficulty to perform a behavior) is found to be non-contributory in the context of textile firms of Bangladesh. Findings imply that government, non-government and other policy makers are expected to emphasize compulsory environmental reporting disclosure to form a more environmentally responsible society.

Keywords: Environmental Reporting, Sustainable Development Goals; Theory of planned behaviour, Bangladesh.
\end{abstract}

*Corresponding author: S.M. Shafiul Alam; Email: shafistore@gmail.com

DOI: https://doi.org/10.37227/JIBM-2019-04-24

\section{Introduction}

It is has become obvious from contemporary scientific investigation that there is a positive association between carbon emissions, energy consumption and economic progress (Ntanos, Kyriakopoulos, Chalikias, Arabatzis, and Skordoulis, 2018). Hence, Firms are frequently held accountable as a performer in the shifting climate, directly or indirectly. Moreover, they are being forced to evaluate, lessen and report their Green House Gases (GHG) emissions by diverse stakeholders (Guenther, Guenther, Schiemann, and Weber, 2016; Haque and Deegan, 2010). In response to this pressure, a number of firms around the globe have started 
to devise strategies and endeavor to disclose different voluntary information about GHG emissions in environmental reporting (ER) (Lee, Park, and Klassen (2015).

ER serves three basic functions such as disclosing information on the basis of societal accountability of organizations, providing valuable information for decision making and encouraging ecological initiatives. With a view to addressing such benefits, a rising number of voluntary and obligatory ER arrangements have been initiated by various governments such as United States of America, Australia, Canada, France, Japan, Israel, Korea, New Zealand and United Kingdom. A wide range of non-governmental initiatives have been extended with the aim of forcing firms to disclose environmental credentials about their effects on the environmental performance. Examples of these endeavors include the Carbon Disclosure Project (CDP), the Institutional Investor Group on Climate Change (IIGCC) etc. (KPMG, 2007).

Application of the concept of environmental sustainability is relatively new in Bangladesh. Over last two decades, the Government of Bangladesh (GOB) undertook expedient steps in order to initiate institutional changes. It is to be noted that ER is still not compulsory in most of the business sectors of Bangladesh. Several firms have established different strategic approaches with regard to voluntary ER. Some of the firms are still engaged in avoiding transparency and continued not to disclose any ecological information at all while some of the firms have chosen to deliver detailed information about their ecological performance and GHG emissions voluntarily (Cotter and Najah, 2012)

This study attempts to understand the interplay among the major determinants of environmental voluntary disclosure intentions of Bangladeshi textile firms by applying the theory of planned behavior (TPB). Literature reveals that there is a great deal of overlap among theories which would provide valuable insights justifying the intention for reporting environmental information (Deegan, 2002). Socio-political theories (Gray, Kouhy, and Lavers, 1995) contend that environmental disclosures are a consequence of social and political pressures. Firms with poor environmental performance come across these pressure and generally find greater incentives to disclose environmental information in order to change perceptions of stakeholders. However, these theories are partly successful in elucidating an independent behavioral intention like intention of manager towards ER. The Theory of planned behavior, in this case, would be most suitable for explaining behavior that are controlled by intensions. TPB has been found to be well supported by empirical evidences. Intentions toward environmental behavior can be predicted with higher level of accuracy by attitudes toward the behavior, subjective norms, and perceived behavioral control. Moreover, It is also evident that TPB model could be extended together with morality impact which can explain managers intention for engaging in energy savings and carbon reduction behavior that are expected to help mitigate climate change problems (Chen, 2016).

Several previous studies focused on carbon reduction and ER initiatives in developed countries Matisoff, Noonan, and O'Brien, 2013). However, still there is little pragmatic evidences on the ER of firms in developing countries like Bangladesh. In this study, apparel industry of Bangladesh has been selected to collect empirical evidence with a view to predicting environmental disclosure intensions of firms. The study is aimed at making several contributions to the environmental disclosure literature. Firstly, it contributes to the prevailing literature by examining the voluntary behavioral intention of ER of firms operating in a developing country like Bangladesh. Secondly, whilst most of the prior studies examined the determinants and extent of environmental reporting in developed countries, several behavioral factors like - how the company perceive ER; how firms are forced to 
disclose; and how factors hinder or support their intentions towards ER are mostly neglected. On this background, the study augment the existing literature in relation to the firms' attitude, subjective norms and behavioral control towards environmental reporting intensions.

\section{Literature Review}

The TPB model is the extended version of the theory of reasoned action (TRA) which is based on the concept that the intention of performing a specific behavior by an individual is a consequence of some conscious reasoning (Fishbein and Ajzen, 1977). According to TPB attitude, normative force, and perceived control over the behavior determine individual's behavioral intention.

\section{Attitudes towards Environmental Reporting}

Previous studies reveal that in order to perform a specific consistent behavior one has to have rational-choice-based assessment of the consequences towards that behavior (Ajzen and Fishbein, 1977) which is also true for environmental performance. In relation to ER, attitudes of managers for disclosing voluntary environmental information can be identified by how they justify environmental reporting. Jacobs, Singhal and Subramanian (2010) argued that enhanced environmental performance (EP) can reveal opportunities to access to new markets. Improved EP can also reduce non-value adding costs leading to improved economic performance which ultimately results in augmented revenue (Jacobs et al., 2010). The literature suggests that voluntary disclosure may narrow information asymmetry and reduce financing costs (Healy and Palepu, 2001). Based the findings of the above studies, it has been projected that managers' attitude is positively connected to their intention to engage in ER. In this connection the following hypothesis has been developed:

$\mathrm{H}_{1}$ : Firm's attitude towards ER positively influences their intention to engage in ER.

\section{Subjective Norms Towards Environmental Reporting}

Subjective norms can be understood as the strength of normative beliefs and the inspiration to comply with these beliefs. Ajzen and Fishbein (1977) recommended that the perceived social pressure has substantial impact on behavioral intentions. On the basis of signaling theory, firms should disclose value relevant information to fulfil the demands of investors for information. Non-governmental agencies force state government to control environmental conduct of firms in the global economy as an imperative mechanism to decrease their carbon emissions (Ennis, Kottwitz, Lin, and Markusson, 2012). The community exerts social pressure on the initiatives of firms concerning ecological issues. Legitimacy theory postulates that organizations continue within the boundaries of social values (Deegan and Rankin, 1997) and there is innate social contract between the organization and the society (Solomon and Lewis, 2002). This pressure provides executives with the drive to reveal and thereby legitimize their long-term operational sustainability (Mobus, 2005; Cho and Patten, 2007). The following hypothesis represents the link between ER and the intention to engage in ER:

$\mathrm{H}_{2}$ : Firm's subjective norms regarding ER positively influences their intention to engage in ER

\section{Perceived Behavioral Control to Environmental Reporting}


Perceived behavioral control can be defined as the perceptions of individuals about their capability of performing a given behavior. Researches revealed that on an average 15 percent of firms report environmental disclosure in response to legitimacy exposures and external stakeholder pressure (Sullivan and Gouldson, 2012). Though Firms are compelled by investor for ER, managers paid less concern to the worth of the reported material due to lack of integrity. Furthermore, specific organizational systems for performing full-fledged environmental reporting are recognized to be crucial to enable firms to monitor, measure and record carbon emission levels (Rankin, Windsor, and Wahyuni, 2011). This study hypothesizes that managers' perceived behavioral control is positively associated to their intention to engage in ER:

H3: Firms' perceived behavioral control over ER positively influences their intention to engage in ER.

\section{Behavioral Intention to Engage in Environmental Reporting}

The behavioral intention is understood as the precursor leading to the actual behavior. Intention to install specific internal system of practicing environmental reporting to construct consciousness among management personnel can be a sign of performing environmentally well. According to Adams (2002), forming an environmental committee as a part of the board committee structure is reflected as an important intentional factor (Peters and Romi, 2012). Involvement in strategic corporate social responsibility (CSR) especially community development, environmental stewardship, international responsibility and accountability can also be an indication of EP. For instance, a number of firms in China have adopted environmental risk management system concentrating on emergency response, prevention and mitigation of environmental risks (Mol, He and Zhang, 2011).

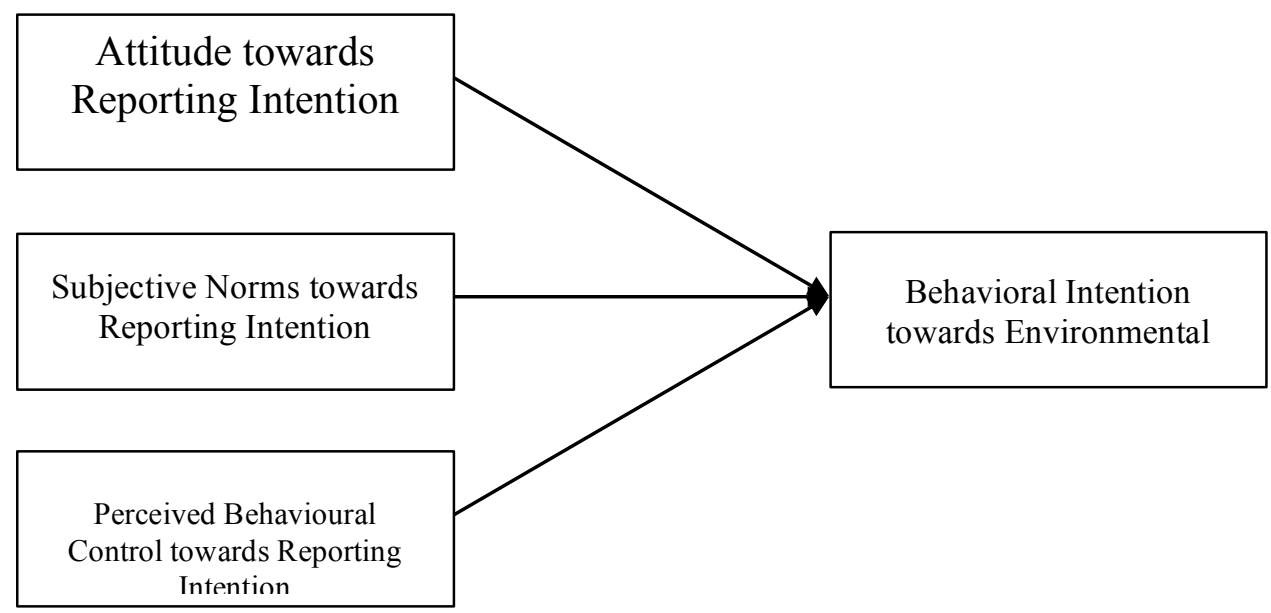

Figure 1: Research Framework

\section{Data Collection and Sample}

\section{Methodology}

A self-reported questionnaire survey has been carried out in July, 2018 on Textile factories of Bangladesh. The study used random sampling based on 53 textile firms enlisted with Dhaka Stock Exchange. 530 questionnaires were sent for collecting data. Mid and top level management employees were nominated as respondents since they are expected to retain authoritative power to take pertinent operational and managerial decisions. Total 480 
questionnaires were returned and 415 of them were found workable for the analysis with a successful response rate of $78.30 \%$.

\section{Measures}

In order to measure the constructs of the study, the measurement scale and the indicator variables adopted were supported by previous studies. The scale developed by Fishbein and Ajzen (1977) for the components of the TPB model has been adapted for the analysis. A four-item attitude measurement scale was utilized to measure attitude towards ER. Following Kim, Jeong, and Hwang (2013) and Han, Hsu, and Sheu (2010), a three-item measurement scale regarding subjective norm was utilized to ascertain whether significant pressure group would approve certain behavior concerning ER. Following Han et al. (2010), a three-item perceived behavioral control measurement scale was utilized to measure perceived capabilities of performing environmental behavior. A five-item scale was used to understand intention to engage in environmental behavior for preparing reports which has been adapted from the study of Smith and McSweeney (2007). This study used 5-point Likert scale with 1 indicating "strongly disagree" and 5 "strongly agree." The detailed scale items of the constructs have been included in the Appendix.

\section{Data Analysis and Results}

Structural equation modeling (SEM) permits understanding of complex phenomena with multiple observed variables. Moreover, it takes latent and observed variables as well as measurement error terms into consideration while analyzing data. With a view to achieving the objectives of the study, SEM was utilized to examine the explanatory power of the theory of planned behavior (TPB) model in predicting intention of managers towards environmental reporting in the apparel sector of Bangladesh. The two-step analysis has been employed for implementing SEM which was devised developed by Anderson and Gerbing (1988).

\section{Measurement Model Analysis}

The quality and adequacy of the measurement model were tested by investigating reliability, convergent validity, and discriminant validity. Since the chi-square statistic is overly sensitive to sample size, the adequacy of the measurement model is evaluated by other goodness-of-fit criteria (Joreskog and Sorbom, 1996). In order to ensure adequate fitness of the model with data, the following fit indices are adopted: (1) chi-squared/d.f. ratio is considered satisfactory when the ratio is smaller than 5 (Marsh and Hau,1996); (2) the root mean squared error approximation (RMSEA) and the root mean square residual (RMR) is considered acceptable when the values are less than 0.08 ; (3) the goodness-of-fit index (GFI), the adjusted goodness-of-fit index (AGFI), the comparative-fit index (CFI), non-normed Index (NNI), and the normed-fit index (NFI) are found acceptable when corresponding indices are greater than 0.90. As suggested by Marcoulides and Schumackers (1996) the results of Confirmatory Factor Analysis (CFA) and structural model are shown in the first two columns in Table 1 indicating satisfactory fit for the measurement model.

Table 1: The Fit Indices of Measurement Model and Structural Model

\begin{tabular}{lcc}
\hline & Measurement & Structural \\
& Model & 127.369 \\
\hline Chi-square value & 127.369 & 84 \\
Degrees of freedom & 84 & 1.516 \\
Chi-squared/d.f. ratio & 1.516 & .034 \\
Root mean squared error approximation (RMSEA) & .034 & .040 \\
Root mean square residual (RMR) & .039 &
\end{tabular}




$\begin{array}{lll}\text { Goodness-of-fit index (GFI) } & .959 & .959 \\ \text { Adjusted goodness-of-fit index (AGFI) } & .941 & .941 \\ \text { Comparative-fit index (CFI) } & .926 & .926 \\ \text { The normed-fit index (NFI) } & .816 & .816\end{array}$

The descriptive statistics and pair-wise correlation matrix of the constructs are produced in Table 2. All pair-wise correlations of the constructs have been found statistically significant at $\alpha=0.01$ level. The correlations range from 0.48 (attitude towards reporting and subjective norms) to 0.14 (perceived behavioral control and subjective norms). The internal consistency of the indicator variables is measured by the most widely used criterion Cronbach's $\alpha$ (Cronbach, 1951). The reliability analysis of the scales of the measurement model reveals that all variables measured were found reliable with reliability coefficient values alpha $(\alpha)$ higher than the threshold level of 0.7 (see Table 5). The internal consistency of each construct has been achieved by convergent and discriminant validity measures.

Table 2: The Descriptive Statistics and Correlation Matrix of Studied Constructs

\begin{tabular}{lcccccc}
\hline & Mean & $\begin{array}{l}\text { Standard } \\
\text { deviation }\end{array}$ & RA & SN & PBC & RI \\
\hline Reporting Attitude (RA) & 3.625 & 0.767 & 1.000 & & & \\
Subjective norms (SN) & 4.043 & 0.598 & $.484^{* *}$ & 1.000 & & \\
Perceived behavioral control (PBC) & 2.341 & 0.829 & $.173^{* *}$ & $.149^{* *}$ & 1.000 & \\
Reporting intension (RI) & 2.887 & 0.737 & $.451^{* *}$ & $.282^{* *}$ & $.388^{* *}$ & 1.000 \\
\hline
\end{tabular}

**Correlation is significant at the 0.01 level

Construct validity attests how well the results obtained from the use of the measure fit the theories around which the test is designed (Sekaran and Bougie, 2010). Convergent validity signifies to the degree to which scores on a test associate with (or are related to) scores on other tests that are designed to assess the same construct. Table 3 shows that all items measuring the same construct loaded satisfactorily on that particular construct and loaded lower on other constructs indicating convergent and discriminant validity. As suggested by Hair, Black, Babin, and Anderson (2010) the study used factor loadings, composite reliability and average variance extracted (AVE) to assess convergent validity. The loadings of all items safely exceeded the threshold value of 0.5 (Hair et al. 2010). Composite reliability values (see Table 3 ) which depict the degree to which the construct indicators conform to the latent construct ranged from 0.859 to 0.902 exceeding the threshold value of 0.7 (Hair et al., 2010). The AVE measures the variance captured by the indicator variables in relation to measurement error, and it should be greater than 0.50 to justify using a construct (Hair et al. 2010). The values of AVEs were in the range of 0.609 and 0.742 . Discriminant Validity determines whether the constructs in the model are highly associated among them or not. It compares the square root of AVE of a specific construct with the correlation between that construct with that of other constructs. The values of square root of AVEs should be higher than those of other correlations. 
Table 3: Convergent and Discriminant Validity Measures

\begin{tabular}{lcccccccc}
\hline & CR & AVE & MSV & MaxR(H) & RA & SN & PCB & RI \\
\hline RA & 0.896 & 0.742 & 0.175 & 0.900 & $\mathbf{0 . 8 6 1}$ & & & \\
SN & 0.886 & 0.609 & 0.241 & 0.901 & 0.418 & $\mathbf{0 . 7 8 1}$ & & \\
PCB & 0.902 & 0.697 & 0.310 & 0.911 & 0.193 & 0.491 & $\mathbf{0 . 8 3 5}$ & \\
RI & 0.859 & 0.669 & 0.310 & 0.859 & 0.168 & 0.307 & 0.557 & $\mathbf{0 . 8 1 8}$ \\
\hline
\end{tabular}

\section{Structural Model Analysis}

The study evaluated the explanatory power of TPB model in predicting managers' ER intention to enhance their EP. According to Marsh and Hau (1996) and Marcoulides and Schumacker (1996), the results revealed in the last column in Table 1 indicate an acceptable fit for the structural model. The results of the TPB model reveal that the three antecedent constructs included in this model can explain about $35 \%$ of the variance on the intention to engage in ER behavior signifying the environmental performance. The estimates of the path parameters are shown in Table 4 indicating that attitude towards ER $\left(b_{R A}=0.334, \mathrm{t}=6.133\right)$, subjective norms $\left(b_{S N}=0.416, \mathrm{t}=6.088\right)$, and perceived behavioral control $\left(b_{P B C}=0.019\right.$, $\mathrm{t}=.298$ ) are positive contributors to intention to engage in ER behavior as expected. The results verify that the components included in the TPB model would exert their impacts on intention towards disclosing environmental information to users.

Table 4: The path coefficients of the structural model

\begin{tabular}{clccc}
\hline Hypothesis & \multicolumn{1}{c}{ Path } & $\begin{array}{c}\text { Standardized } \\
\beta\end{array}$ & $\begin{array}{c}t \text { - } \\
\text { value }\end{array}$ & $\begin{array}{c}p \text { - } \\
\text { value }\end{array}$ \\
\hline$H_{1}$ & $\begin{array}{l}\text { Reporting attitude (RA) } \rightarrow \text { Reporting } \\
\text { intention }\end{array}$ & 0.334 & 6.088 & $<0.01$ \\
$H_{2}$ & $\begin{array}{l}\text { Subjective norms }(\mathrm{SN})) \rightarrow \text { Reporting } \\
\text { intention }\end{array}$ & 0.416 & 6.133 & $<0.01$ \\
$H_{3} \quad$ & $\begin{array}{l}\text { Perceived behavioral control (PBC) } \rightarrow \\
\text { Reporting intention } \\
\text { Squared multiple correlation }\left(R^{2}\right)\end{array}$ & 0.019 & 0.298 & N.S. \\
& & $35.0 \%$ & & \\
\hline
\end{tabular}

\section{Discussions}

The findings suggest that firms' intention to engage in environmental reporting (ER) is likely to be influenced by personal attitudes regarding the value of reporting, perceptions of whether internal and external stakeholders approve ER, and perception of the availability of resources and lack of hindrances to enable ER. The results of the analysis indicate that the effect of subjective norms has the greatest influence on intention to engage in environmental reporting behavior. Islam, Miah, Asaduzzamam (2015) concluded with a similar notion that without strict accounting pronouncements from the Institute of Chartered Accountant Bangladesh (ICAB) and disclosure norms by other related regulatory authorities, the Firms generally provide only some qualitative and positive information about environment. Sakamoto, Ahmed, Begum, and Huq (2019) stated that inadequate monitoring and enforcement by the government authorities induced low willingness of Firms to engage in environmental protection activities and reporting. However, theoretically, attitude tends to be a stronger determinant of intention than the other factors (Ajzen, 1991). Testa, Gusmerottia, Corsini, Passetti, and Iraldo (2016) found that entrepreneurs' attitudes are considered as the most important predictors of environmental pro-activity both for small and micro firms. It is undeniable that the environmental reporting behavior of firms would be 
revealed if firms act ethically, be responsible in energy saving, reduce carbon footprint, and disclose environmental accounting information. Thus, the intention to engage in that particular reporting behavior would grow if managers show positive attitude towards environmental reporting. In contrary to this point of view, Raab, Baloglu, and Chen (2018) concluded that "Attitude" did not have any influence on managers' intentions to implement sustainable practices. Authors argued that the findings of this study is logical, since managers in the businesses are generally very practical about their ability to perform, feasibility of the action to be performed and the perceived outcome. Hence, their personal attitude towards a behavior does not make significant impacts on actions they take.

However, our results reveal that in the context of ER all three factors influence environmental intention positively. In this study, subjective norm is the strongest determinant of intention towards ER for the organizations which is in line with the study by Thoradeniya, Lee, Tan, and Ferreira (2015). It is worthwhile to note that the empirical results obtained from the TPB model indicate that perceived behavioral control is not a contributor to firm's intention to engage in environmental reporting behavior. According to Kaiser and Gutscher (2003), perceived control over behavior has least direct influence on behavioral intension. Sakamoto et. al (2019) have found similar result while studying corporate practice to mitigate environmental pollution in Bangladeshi textile firms. According to Bandura (1986), humans are social beings who rely upon each other to find way outs of a problem and always seek for an improved situation in the efforts of others at first hand. Significant effects in pro-environmental behavior would be found if large a number of actors (e.g., Firms and industry lines, politicians and administrators, consumers, common people, researchers/ engineers) participate and these changing processes may take time to flourish (Bamberg, Rees, and Schulte, 2018).

\section{Conclusion}

This study attempted to explain firms' behavioral intentions in relation to environmental reporting in Bangladesh through the application of theory of planned behavior. The results advocates that the TPB model has a reasonable explanatory power in predicting firm's intention to engage in environmental reporting behavior. This study delivers both theoretical and managerial implications regarding firms' intention to engage in environmental behavior. In relation to previous studies, results of the analysis suggests that the contribution of situational factors (i.e., perceived behavioral control) in predicting intention to engage in environmental reporting behavior is limited. Findings suggest that firms' intention to engage in environmental reporting behavior is mostly influenced by its subjective norms and perceived behavioral control. This outcome signifies that if a firm maintains strong social attachment, peer pressure, and substantive bindings form different authoritative bodies then it would more likely to engage in carbon reduction and environmental reporting behavior. This indicates that in order to enhance firm's intention to engage in environmental reporting behavior, governmental and non-governmental policy makers should pay more attention to hold Firms accountable while operating businesses.

Nevertheless, the behavioral intention models have been acknowledged with robust support in numerous behavioral domains, prior studies of TPB recommend that intention is not a robust predictor of actual behavior, when the behavior is self-reported (Armitage and Conner, 2001) and might be overemphasized considering the possibility of reporting bias. This paradox is the main limitation of the current study. The correspondence between selfreported behavior and observed behavior would not be logically connected. Hence, 
researchers would further investigate to understand this paradox focusing firms' actual carbon reduction behavior in future studies.

\section{References}

Adams, C. A. (2002). Internal organisational factors influencing corporate social and ethical reporting: Beyond current theorising. Accounting, Auditing \& Accountability Journal, 15(2), 223-250.

Ajzen, I. (1991). The theory of planned behavior. Organizational behavior and human decision processes, 50(2), 179-211.

Ajzen, I., \&Fishbein, M. (1977). Attitude-behavior relations: A theoretical analysis and review of empirical research. Psychological bulletin, 84(5), 888.

Anderson, J. C., \& Gerbing, D. W. (1988). Structural equation modeling in practice: A review and recommended two-step approach. Psychological bulletin, 103(3), 411.

Armitage, C. J., \& Conner, M. (2001). Efficacy of the theory of planned behaviour: A metaanalytic review. British journal of social psychology, 40(4), 471-499.

Bamberg, S., Rees, J. H., \& Schulte, M. (2018). Environmental protection through societal change: What psychology knows about collective climate action - and what it needs to find out. In Psychology and Climate Change (pp. 185-213). Academic Press.

Bandura, A. (1986). The explanatory and predictive scope of self-efficacy theory. Journal of social and clinical psychology, 4(3), 359-373.

Chen, M. F. (2016). Extending the theory of planned behavior model to explain people's energy savings and carbon reduction behavioral intentions to mitigate climate change in Taiwan-moral obligation matters. Journal of Cleaner Production, 112, 1746-1753.

Cho, C. H., \& Patten, D. M. (2007). The role of environmental disclosures as tools of legitimacy: A research note. Accounting, organizations and society, 32(7-8), 639647.

Cotter, J., \&Najah, M. M. (2012). Institutional investor influence on global climate change disclosure practices. Australian journal of management, 37(2), 169-187.

Cronbach, L. J. (1951). Coefficient alpha and the internal structure of tests. psychometrika, 16(3), 297-334.

Deegan, C. (2002). Introduction: The legitimising effect of social and environmental disclosures-a theoretical foundation. Accounting, Auditing \& Accountability Journal, 15(3), 282-311.

Deegan, C., \& Rankin, M. (1997).The materiality of environmental information to users of annual reports. Accounting, Auditing \& Accountability Journal, 10(4), 562-583.

Ennis, C., Kottwitz, J., Lin, S. X., \&Markusson, N. (2012).Exploring the relationships between carbon disclosure and performance in FTSE 350 Firms.In 2012 Annual conference of British Academy of Management at Sheffield.

Fishbein, M., \&Ajzen, I. (1977). Belief, attitude, intention, and behavior: An introduction to theory and research.

Testa, F., Gusmerottia, N. M., Corsini, F., Passetti, E., \& Iraldo, F. (2016). Factors affecting environmental management by small and micro firms: The importance of entrepreneurs' attitudes and environmental investment. Corporate Social Responsibility and Environmental Management, 23(6), 373-385.

Gray, R., Kouhy, R., \& Lavers, S. (1995). Corporate social and environmental reporting: a review of the literature and a longitudinal study of UK disclosure. Accounting, Auditing \& Accountability Journal, 8(2), 47-77. 
Guenther, E., Guenther, T., Schiemann, F., \& Weber, G. (2016). Stakeholder relevance for reporting: explanatory factors of carbon disclosure. Business \& Society, 55(3), 361397.

Hair, J. F., Black, W. C., Babin, B. J., \& Anderson, R. E. (2010). Multivariate data analysis: Global edition.

Han, H., Hsu, L. T. J., \&Sheu, C. (2010). Application of the theory of planned behavior to green hotel choice: Testing the effect of environmental friendly activities. Tourism management, 31(3), 325-334.

Haque, S., \&Deegan, C. (2010). Corporate climate change-related governance practices and related disclosures: evidence from Australia. Australian accounting review, 20(4), 317-333.

Healy, P. M., \&Palepu, K. G. (2001). Information asymmetry, corporate disclosure, and the capital markets: A review of the empirical disclosure literature. Journal of accounting and economics, 31(1-3), 405-440.

Intergovernmental Panel on Climate Change (IPCC). (2015)

Islam, M. S., Miah, M. S., \& Asaduzzamam Fakir, A. N. M. (2015). Environmental accounting and reporting: an analysis of Bangladeshi corporate sector. Journal of Business Studies, 2(1/2).

Jacobs, B. W., Singhal, V. R., \& Subramanian, R. (2010). An empirical investigation of environmental performance and the market value of the firm. Journal of Operations Management, 28(5), 430-441.

Joreskog, K. G., \&Sorbom, D. (1983). LISREL VANDLISREL VI: Analysis of linear structural relationships by maximum likelihood and least square methods.

Kaiser, F. G., \& Gutscher, H. (2003). The proposition of a general version of the theory of planned behavior: Predicting ecological behavior 1. Journal of applied social psychology, 33(3), 586-603.

Kim, S., Jeong, S. H., \& Hwang, Y. (2013). Predictors of pro-environmental behaviors of American and Korean students: The application of the theory of reasoned action and protection motivation theory. Science Communication, 35(2), 168-188.

KPMG and Global Reporting Initiative. (2007). Reporting the business implications of climate change in sustainability reports: A survey conducted by the Global Reporting Initiative and KPMG's Global Sustainability Services.

Lee, S. Y., Park, Y. S., \&Klassen, R. D. (2015). Market responses to firms' voluntary climate change information disclosure and carbon communication. Corporate Social Responsibility and Environmental Management, 22(1), 1-12.

Mobus, J. (2005). Mandatory environmental disclosures in a legitimacy theory context. Accounting, Auditing \& Accountability Journal, 18(4), 492-517.

Marcoulides, G. A., \& Schumacker, R. E. (1996).Advanced Capacity equation modelling: Issues and techniques.

Marsh, H. W., \&Hau, K. T. (1996). Assessing goodness of fit: Is parsimony always desirable?. The Journal of Experimental Education, 64(4), 364-390.

Matisoff, D. C., Noonan, D. S., \& O'Brien, J. J. (2013). Convergence in environmental reporting: assessing the Carbon Disclosure Project. Business Strategy and the Environment, 22(5), 285-305.

Mol, A. P., He, G., \& Zhang, L. (2011). Information disclosure in environmental risk management: Developments in China. Journal of Current Chinese Affairs, 40(3), 163-192. 
Ntanos, S., Kyriakopoulos, G., Chalikias, M., Arabatzis, G., \& Skordoulis, M. (2018). Public perceptions and willingness to pay for renewable energy: A case study from Greece. Sustainability, 10(3), 687.

Peters, G. F., \&Romi, A. M. (2012). The effect of corporate governance on voluntary risk disclosures: Evidence from greenhouse gas emission reporting. http://Www. Business. Utah. Edu/Sites/Default/Files/Documents/School-ofAccounting/Ghg_Disclosure_and_Corp_Gov_20120202.

Raab, C., Baloglu, S., \& Chen, Y. S. (2018). Restaurant managers' adoption of sustainable practices: An application of institutional theory and theory of planned behavior. Journal of foodservice business research, 21(2), 154-171.

Rankin, M., Windsor, C., \&Wahyuni, D. (2011). An investigation of voluntary corporate greenhouse gas emissions reporting in a market governance system: Australian evidence. Accounting, Auditing \& Accountability Journal, 24(8), 1037-1070.

Sakamoto, M., Ahmed, T., Begum, S., \& Huq, H. (2019). Water Pollution and the Textile Industry in Bangladesh: Flawed Corporate Practices or Restrictive Opportunities?. Sustainability, 11(7), 1951.

Sekaran, U., \& Bougie, R. (2010). Theoretical framework in theoretical framework and hypothesis development. Research methods for business: A skill building approach, 80 .

Smith, J. R., \&McSweeney, A. (2007). Charitable giving: The effectiveness of a revised theory of planned behaviour model in predicting donating intentions and behaviour. Journal of Community \& Applied Social Psychology, 17(5), 363-386.

Solomon, A., \& Lewis, L. (2002).Incentives and disincentives for corporate environmental disclosure. Business Strategy and the Environment, 11(3), 154-169.

Sullivan, R., \& Gouldson, A. (2012). Does voluntary carbon reporting meet investors' needs?. Journal of Cleaner Production, 36, 60-67.

Thoradeniya, P., Lee, J., Tan, R., \& Ferreira, A. (2015). Sustainability reporting and the theory of planned behaviour. Accounting, Auditing \& Accountability Journal, 28(7), 1099-1137.

Table 6: Appendix

\begin{tabular}{|c|c|c|c|}
\hline $\begin{array}{l}\text { Construct and } \\
\text { Cronbach's } \\
\text { Alpha }(\alpha)\end{array}$ & Mean & $\begin{array}{l}\text { Standard } \\
\text { Deviation }\end{array}$ & Measurement Items \\
\hline \multirow[t]{4}{*}{$\begin{array}{l}\text { Reporting Attitude } \\
\qquad(0.895)\end{array}$} & 3.48 & 0.93 & $\begin{array}{l}\text { I believe environmental reporting helps in achieving } \\
\text { 'Reputation' and 'Accessing to new market'. }\end{array}$ \\
\hline & 3.55 & 0.90 & $\begin{array}{l}\text { In my opinion, environmental reporting results into } \\
\text { 'Increased revenue' and 'Improved economic } \\
\text { performance'. }\end{array}$ \\
\hline & 3.73 & 0.83 & $\begin{array}{l}\text { I think information asymmetry can be reduced and } \\
\text { creditability of reports can be Increased by practicing } \\
\text { environmental reporting. }\end{array}$ \\
\hline & 3.73 & 0.85 & $\begin{array}{l}\text { I observed environmental reporting as a 'Negative signal to } \\
\text { market'. }\end{array}$ \\
\hline \multirow[t]{3}{*}{$\begin{array}{l}\text { Subjective Norms } \\
\qquad(0.847)\end{array}$} & 3.98 & 0.68 & $\begin{array}{l}\text { Investors and Shareholder demand that Firms should report } \\
\text { environmental information to facilitate their decision } \\
\text { making. }\end{array}$ \\
\hline & 4.07 & 0.69 & $\begin{array}{l}\text { Non-government agencies require environmental reports } \\
\text { by the Firms as a measure of environmental performance. }\end{array}$ \\
\hline & 4.08 & 0.68 & $\begin{array}{l}\text { The community where businesses are run think Firms } \\
\text { should report environmental information as a strategy of } \\
\text { environmental protection. }\end{array}$ \\
\hline
\end{tabular}




\begin{tabular}{|c|c|c|c|}
\hline \multirow{3}{*}{$\begin{array}{l}\text { Perceived } \\
\text { Behavioral } \\
\text { Control } \\
(0.893)\end{array}$} & 2.41 & 0.93 & $\begin{array}{l}\text { The decision to practice environmental reporting is } \\
\text { completely up to me }\end{array}$ \\
\hline & 2.38 & 0.97 & I have guidelines and awareness in deciding to what extent \\
\hline & 2.23 & 0.83 & $\begin{array}{l}\text { I have enough opportunities to undergo with required } \\
\text { internal organizational system changes to accelerate } \\
\text { environmental reporting. }\end{array}$ \\
\hline \multirow{5}{*}{$\begin{array}{l}\text { Reporting } \\
\text { Intentions } \\
(0.882)\end{array}$} & 2.74 & 0.83 & $\begin{array}{l}\text { Company has already installed or has an intention to install } \\
\text { EMS }\end{array}$ \\
\hline & 2.88 & 0.90 & $\begin{array}{l}\text { Company has an environmental committee and an active } \\
\text { post of CSO }\end{array}$ \\
\hline & 2.73 & 0.89 & $\begin{array}{l}\text { Company has a disclosed environmental objective and } \\
\text { policies toward achieving those }\end{array}$ \\
\hline & 3.09 & 0.91 & $\begin{array}{l}\text { Company is used to spent a certain amount of budget for } \\
\text { environmental purpose as CSR }\end{array}$ \\
\hline & 2.99 & 0.94 & $\begin{array}{l}\text { Company is taking initiatives to disclose environmental } \\
\text { accounting information on environmental risk } \\
\text { management and social costs thereon. }\end{array}$ \\
\hline
\end{tabular}

